\title{
"Do all roads lead to Rome?": The influence of two different higher education programmes on beginner teacher identity
}

\section{Mické van der Westhuizen}

Faculty of Education, Department of Humanities Education, University of Pretoria, Pretoria, South Africa mickevdw@gmail.com

https://orcid.org/0000-0001-6649-3723

\section{Yolandi Woest}

Faculty of Education, Department of Humanities Education, University of Pretoria, Pretoria, South Africa yolandi.woest@up.ac.za

https://orcid.org/0000-0001-5595-0546

(Received: 29 September 2020; accepted: 3 February 2021)

\section{Abstract}

In this qualitative case study, we explored the experiences of beginner teachers who chose two different routes - full-time and part-time studying — on the journey to becoming teachers and we report on the influences of this choice on their emergent beginner teacher identities. We purposefully selected two groups of participants, each consisting of three who studied full-time and three who studied part-time. The latter worked part-time at schools or in similar educational contexts while they were studying. Epistemologically underpinned by the interpretivist paradigm, we employed the Possible Selves theory (Marcus \& Nurius, 1986) as the theoretical lens. Inductive thematic analysis of data demonstrated three main themes. First, data showed a distinct divergence between the perceptions of initial beginner teacher identity states in the two groups of participants. Second, both groups of participants agreed that time is a significant factor in the complex psychological processes required for the construction of a beginner teacher identity. Third, both groups strongly considered practical experience as an essential factor for beginner teacher identity development.

Keywords: beginner teacher identity, full-time student, part-time student, Possible Selves theory, teacher education programmes

\section{Introduction}

The title of our article refers to the well-known saying, "A thousand roads lead a man [sic] forever toward Rome" coined by French poet Alain de Lille, (cited in Storey, 2008, p. 965). 
Rome was situated at the conjunction of all the main roads of the Roman empire, and was, later, the destination of most of the medieval journeys through Europe as Storey (2008) has reminded us. There are many roads that lead to Rome; some are longer, some shorter, some easier or more difficult to follow, but the desired destination is still Rome. This saying serves as a starting point to our contribution to the existing debates in educational research around the "theory-practice divide in teacher education" (Gravett et al., 2017, p. 370). In other words, we are interested in which of the two teacher education programmes-full-time study or part-time study combined with part-time work in an educational context - taken on the way to becoming a teacher is better or worse in terms of the development of a beginner teacher identity. Depending on which teacher education programme one chooses, there are several different views when it comes to this choice. Levine (2006) has pointed out that some believe that the teaching profession calls for a vast volume of formal pre-service education as a condition for one to develop into a practitioner, much like becoming a doctor or a lawyer, while others consider teaching to be a skill that is learned primarily on the job, like, it could be argued, journalism.

In this article, we explore the ways in which the choice of road towards that metaphorical Rome influences the identities of the travellers. To do so, we delved into the experiences of beginner teachers who chose different routes to becoming teachers and we report on the influences of this choice on their emergent beginner teacher identities. Our aim was not to compare differences between teacher programmes per se but, rather, to try to understand the lived experiences of pre-service teachers who took these two different routes to becoming teachers and show how these experiences influenced their beginner teacher identities. We consider here the influences of only two different paths (full-time and part-time teacher education programmes) on beginner teachers' identities.

Prospective students aspiring to become teachers, enrol in teacher education programmes with certain preconceived expectations of what it means to be a teacher (Yuliyana, 2019). Then, in many cases, beginner teachers who studied full-time consider their professional courses at tertiary institutions as consisting of too much theory and not sufficient practical knowledge and they have reported a sense of dissonance when faced with the real situation in schools during their early years in the profession (Lambert, 2010). However, the influence of the chosen path taken towards becoming a teacher is a much more complex process than prospective pre-service teachers anticipate or understand (Beltman et al., 2015; Langsford, 2020). In this article, we unpack the ways in which different roads influence beginner teachers and consider what it is that influences that sense of dissonance mentioned by Lambert (2010).

During the course of their studies, pre-service teachers construct their individual teaching identities, which change later into the teaching identities they need if they are to adapt in the real school environment (Yuliyana, 2019). Initial beginner teacher identities are vulnerable during the early years in the profession because of the daily demands that they face. Much has been written about these challenges and the influences thereof on beginner teacher identity (see, for example, Dicke et al., 2014; Klusman et al., 2016; Kumazawa, 2013). 
Tertiary training institutions are the spaces within which pre-service students' beginner teacher identities, influenced by their perceptions, begin to develop formally. Thus, the tertiary training institution of choice should be conducive to growth and development for emergent beginner teacher identities since this development frames, significantly, the process of learning to teach (Nomlomo \& Sosibo, 2016). The experiences of pre-service teachers during their years of study at these institutions might influence their development during their early years in the education profession.

Having set the scene of this paper, we go on to frame our study in relation to the relevant literary scholarship. Then we discuss the theoretical underpinning of the research question in terms of the Possible Selves theory as suggested by Marcus and Nurius (1986), and argue for our research methodology, after which we present the findings and a discussion of them.

\section{Framing our study in literary scholarship}

In this section we present a discussion of recent scholarly debates involving the key concepts of our paper: initial beginner identity states; the influences of the challenges experienced by beginner teachers; and the role of teacher training programmes as influential on beginner teacher identity. Additionally, to provide some background to our study, we provide a brief historical overview of these concepts.

\section{The development of beginner teacher identity}

The effectiveness of beginner teachers is influenced by their personal backgrounds (past self), their formal training (teacher educational programme) and the context of their school placements (practical experience) as Hofmeyr (2016) has pointed out. Current academic research has started to shift its focus towards the important question of how teachers learn (Korthagen, 2017). Many teacher educators object to a professional teacher obtaining just practical tools for handling classroom situations and suggest that it is their job to present preservice teachers with a broader view on education and to offer them a proper foundation in psychology, sociology, and other disciplines (Korthagen et al., 2001). Twenty-six years ago, Clandinin (1995, p. 28) called this issue "the sacred theory-practice story" which many teacher educators have understood to be about the conversion of theory on good teaching into lived classroom practice. However, many studies have shown that the transfer of theory to practice is still inadequately achieved or is not achieved at all (Abongdia et al., 2015; Korthagen et al., 2001; Nomlomo \& Sosibo, 2016). For the beginner teacher, what was understood theoretically, now becomes complex since they must now use practically the knowledge and understanding of the theory to guide their actions, communication, and socialisation in order to fit in with the culture of the school (Padua \& Franca-Carvalho, 2019). Put differently, a beginner teacher who studied full-time may have the theoretical background provided by their teacher education programme but may lack the practical teaching skills.

Any attempt to make more explicit the link between theory and teaching practice is pointless without sufficient knowledge about how teachers learn (Korthagen, 2017). Gravett (2012, p. 
3) argued that "no teacher education programme can prepare teachers for the full complexity of real classrooms, where they take full responsibility for the first time." In accordance with this statement, Feiman-Nemser (2001, p. 1,026) noted,

New teachers have two jobs - they have to teach, and they have to learn to teach. No matter how good a preservice program may be, there are some things that can only be learned on the job. The preservice experience lays a foundation and offers practice in teaching. The first encounter with real teaching occurs when beginning teachers step into their own classroom. Then learning to teach begins in earnest.

The conversation about the "the sacred theory-practice story" (Clandinin, 1995, p. 28) was continued 19 years later by Tamrat and Teferra (2020). In an online article in World News, they discussed a "diversified means of educational delivery, in particular a non-residential model, that may become more mainstream, more acceptable and more respectable." Tamrat and Teferra (2020) agreed with the views of South African scholars Maphalala and Mpofu (2019, p. 3), who wrote that "the education system must create conducive working conditions, which will ensure the retention of teachers, especially those with the most experience and with scarce skills."

The independent Carter Review (2015) found difficulty drawing conclusions about whether one route into teaching is better than the other since both routes had their strengths (practical experience vs theoretical knowledge) although programmes that offered more practical experience brought benefits and delivered important preparation options to improve the quantity and quality of teachers (Hofmeyr, 2016). The link between practice and theory in pre-service teacher learning is not exclusively important; the connection with the person of the teacher is significant as well. Connecting to your teaching identity through in-depth reflection is an important device in establishing rewarding links between theory, practice, and person (Korthagen, 2017).

It is in the classroom setting that many of the beginner teachers' knowledge about everyday life as a teacher is used as a basis for inspiration, and where contextualisation of pedagogical practice is experienced (Padua \& Franca-Carvalho, 2019). Many pre-service teachers acquire a deeply rooted perception of teaching and learning from their own educational experiences before they start as a beginner teacher which will guide their choice of route (Nomlomo \& Sosibo, 2016). Lortie (1975, p. 35) referred to these early ideas formed about teaching as an "apprenticeship of observation", a view upheld by Gravett et al., (2017, p. 370) who posited that the "images of teaching developed during student-teachers' own school years form the basis for interpreting and assessing conceptual knowledge and their learning experiences as student-teachers." These moments are imperative to the forming of a student's identity, and are, in turn, likely to then have an impact on their future teaching identity.

\section{Challenges during early years: Learning to teach in difficult contexts}

Adding to the complexity of the beginner identity construction process is the matter of challenges experienced by beginner teachers during their early years in the profession. As 
early as the 1980s challenges faced by beginner teachers have been documented in scholarly literature in the field. The struggles associated during the early years of beginner teachers in the profession have been described as "transition shock" (Corcoran, 1981, p. 19), "reality shock" and "the survival phase" (Huberman, 1989, p. 57). The scholarly debate surrounding the demands on beginner teachers are ongoing (Friedman, 2000; Klusman et al., 2016; Stokking et al., 2003).

In many cases, beginner teachers feel isolated and perceive school management teams and more experienced colleagues as hostile and unfriendly (Flores \& Day, 2006). Additionally, beginner teachers experience conflict with their colleagues since they are unfamiliar with the different ideologies prevailing in the schools (Deswita, 2019). They also find it difficult to establish and maintain discipline especially in large, overcrowded classroom contexts which are common in South Africa (Woest, 2018). Often, beginner teachers face difficulties with learners because they have not yet become skilled at problem-solving (Deswita, 2019). Friedman (2000, p. 182) described the realisation of the chasm between the period of teacher training and the early years of teaching as a case of "shattered dreams." It is therefore important to take a step back and explore the teacher identity-building experiences of preservice teachers during their years of training.

\section{Initial beginner teacher identity as a complex construct}

Studies on beginner teacher identity deal with the initial processes of the construction of a specific professional identity as a teacher. The process of

learning or developing a teacher identity is imbued with and fuelled by many aspects that are primarily personal, such as one's own biography, aspirations, learning history, and beliefs about education ... [including] the hopes, dreams, and ideals that students bring with them to teacher education" (Beijaard, 2019, p. 3).

Positive psychology promotes the consideration of personal qualities, which centre on people's wellbeing and positive growth and, in turn, influence the formation of their teaching identity (Korthagen, 2017).

Over the last few decades, various researchers have explored the progression of a pre-service teacher becoming a teacher, as well as their first years in teaching (Beauchamp \& Thomas, 2009, 2011; Flores, 2017; Pillen et al., 2013; Yuan \& Lee, 2016). Beginner teacher identity development implies the initial and sometimes volatile psychological, mental, cognitive, and behavioural processes pre-service teachers undergo to arrive at a stable, yet fluid, teacher identity. It is important to note that professional identity (in this case teacher identity) is not fixed or static; it is, rather, a dynamic and continually changing process. In this paper, we consider only one slice of this ever-changing process - the identity states of pre-service teachers during the transitioning process of their becoming beginner teachers.

Investigation into both the inward and outward manifestations of beginner teachers' theoretical and actual growth towards becoming a teacher is necessary. How their teacher 
identity develops may be influenced by their own critical self-examination, but attention must also be given to the school environment and to their learners and colleagues since these operate in conjunction with one another (Lee \& Schallert, 2016). During this process, beginner teachers begin to solidify their construct of self as their understanding of the basic nature of teaching grows.

Accentuating the intricacy associated with learning to teach, Darling-Hammond et al. (2005, p. 368) specified that "even when observing good teaching or experiencing it for oneself, one cannot easily glean a deep understanding of the complexity of the work." A thorough comprehension of one's teaching self contributes to the success of beginner teachers during their early years of teaching and, thus, to a positive career trajectory. The ability to make meaning of experiences and find ways to overcome challenges in an unfamiliar and new professional environment strengthens the sense of the professional self and promotes the resilience of the beginner teacher. We argue that the choice of tertiary education programme is an often-overlooked influence in the process of the construction and development of the identity of the beginner teacher.

The role of teacher training programmes in influencing beginner teacher identity

The route chosen by pre-service teachers to become qualified teachers is one of many factors that influence their teacher-becoming during their early years in the profession. Hofmeyer (2016) suggested that the choice of educational programme is one of the influences on the effectiveness of beginner teachers and that this is based on the balanced construction and development of a stable initial beginner teacher identity. Much of what is taught at universities are concepts and conceptual frameworks related to phenomena, principles, and facts. In other words, university learning involves "learning about" (Gravett, 2012, p. 3), but learning should also be understood with regard to the development of a teaching identity, i.e. "learning to be" (Gravett, 2012, p. 5). To a degree, beginner teachers' identity is constructed from their initial teacher education programme, complemented by their individual teaching experience; together these motivate and result in the development process of skills and teaching methods (Padua \& Franca-Carvalho, 2019).

Many pre-service teachers in South Africa follow the international traditional norms by pursuing a four-year university-based programme. These programmes are provided by 23 universities with either distance or face-to-face education, include both professional and academic modules, and are interspersed with varying periods of supervised teaching practice in schools as part of the preparation for pre-service teachers' work in schools as Hofmeyr (2016) has observed. The idea that universities do not prepare pre-service teachers effectively for the realities of classroom teaching is not exclusively a South African one (Gravett, 2012). In some countries a key part of pre-service teacher education has now become the concern of the schools, thus creating a situation in which teacher education takes the form of "training on the job" (Korthagen et al., 2001, p. 2). The teacher education curriculum in the United States of America has been divided, historically, between foundations modules, on the one hand, and methods modules on the other (Grossman et al., 2009). 
One of the main points of teacher education programmes abroad is that they promote a close relationship between the tertiary institution and the schools that host students for their practical term. There is a system of "studying theory from books and in lectures" and then applying it practically in what is termed the "real world" (Gravett, 2012, p. 4). According to Hofmeyr (2016), a key flaw identified in university curricula worldwide is the lack of sufficient school practical experience. Although all university-based teacher education programmes include many field experiences during the programme (as a requirement in South African initial teacher education policy according to The Revised Minimum Requirements for Teacher Education Qualifications, Department of Higher Education and Training, 2015), the gap between what students are taught in university modules and their opportunities for learning to enact these practices in their school placements is often still very large (Zeichner, 2010).

Although student life plays a particular role in higher education since students attend classes with the intention of learning which is made viable by attending classes, but which also occurs in the teachable moments that arise inside and outside the classroom (Mitchell, 2014). However, some universities in South Africa employ Open Distance Learning, which stipulates that all students (including pre-service teachers) must study part-time (Hofmeyr, 2016). Part-time students can work even as they study, whereas full-time students become part of the student culture mentioned above. In Open Distance Learning, course and study materials are supplied in the absence of a university intermediary, and students must interrogate these individually and in their own time (Hofmeyr, 2016). Moreover, working full-time at a school while studying part-time can also be extremely challenging and difficult for students given that they have to "grapple with meeting the requirements of both the university programme and the school-based curriculum, which may be in tension with each other" (Chan, 2019, p. 3).

Limited research about different teacher education programmes in relation to beginner teacher identity development is apparent in the literature we reviewed. Incomplete research on the influence of teacher education programmes on beginner teacher identity was pointed out by scholars in the field (Beauchamp \& Thomas, 2009; Cherrington, 2017; Chubbuck et al., 2001; Du Plessis \& Sunde, 2017). Most of the past research on beginner teacher identity is based on identities and factors that influenced them (see Canrinus et al., 2012; Hobson et al., 2009; Hong, 2010; Nomlomo \& Sosibo, 2016), except for the influence of teacher education programmes.

\section{Theoretical framing}

Our research is framed theoretically by the Possible Selves theory (Marcus \& Nurius, 1986). This theory concentrates on investigating the growth of beginner teachers' identity as Hamman et al. (2010) have pointed out. It also concerns beginner teachers' establishing their individual beginner teacher identity in their changeover to becoming teachers. The Possible Selves theory is appropriate because it accounts for the fluctuating states of the professional self of the beginner teacher during the transition process from pre-service teacher to beginner 
teacher. The use of the Possible Selves theory as a lens through which to view the formation of beginner teacher identity has not been well-researched but see, for example, Hamman et al. (2010), Lee \& Schallert (2016), and Yavuz Tabak (2020); most literature focuses on either beginner teacher identity or on the Possible Selves theory, but not on both. The limited nature of this research prompted us to use this theory given our belief that it is still relevant many decades later.

The Possible Selves theory (Marcus \& Nurius, 1986) posits that at the beginning of a teacher's career, they might have a handful of ideas regarding the type of teacher they want to be (future self) based on their past experiences (past self). During their pre-service years and first years of in-service teaching, these identity states will change and evolve as they experience the realities of a classroom setting, are exposed to external factors, and carry out personal experimenting with their teaching identities. The beginner teacher's identity will therefore have an impact on their identity as moulded in their first years of teaching. The Possible Selves theory moulds a person's idea of what they want to mature into. This theory not only illustrates who it is that someone wants to grow into but also who they fear becoming. The Possible Selves theory illustrates how future-oriented thought is driven by the pursuit of self-relevant goals, and how it delivers identity-relevant information (Hamman et al., 2010). Possible future selves are characterised by specific, individually unique hopes, fears, and fantasies and are not just any set of fictional states of being (Marcus \& Nurius, 1986). For the beginner teacher's identity, this includes their own hopes and fantasies as well as their fears about the kind of teacher they want to become in the future. The Possible Selves theory also includes the beginner teacher's past self. In this case, these are their experiences from their chosen teacher education programme. When beginner teachers enter the teaching profession, their emergent beginner teacher identities have already undergone some changes marked by previous experiences during their years of training and might at this point be in flux as they start out in a new and unfamiliar environment, (Woest, 2018). We build further on this theory in the discussion of our findings.

\section{Research context and methodology}

We employed a nominalist, interpretivist, qualitative methodological paradigm, with, following Zartman and Goodrick (2005), a single case study as research design. A qualitative methodological paradigm is an approach that strives to explore and understand the meaning participants have of their social problem(s) without manipulating the data as Creswell (2008) has explained. Qualitative research allows for the gathering of stories in a personal environment. In the context of this study, it meant gathering the stories of beginner teachers with different teacher education backgrounds-full-time and part-time.

Ontology can be seen to relate to our views of the world together with how we perceive reality (Denzin \& Lincoln, 2008) so, for us, a nominalist stance was appropriate because this showcases the importance of participants' internal and subjective experiences as Maree (2016) has noted. Epistemology is related to the relationship between the inquirer and the known as Denzin and Lincoln (2008) have explained. An epistemological perspective can be 
either positivist or interpretivist according to Cohen et al. (2007). As Snape et al. (2014) have established, interpretivism strives to understand meaningful, subjective experiences as well as the meaning behind social interactions in a personal context. Interpretivism allows for a subjective participatory role in the research process, while one is being empathetically and personally immersed in the research (Maree, 2016). The participants interpreted their own teaching identities differently so, in being subjectively involved we could better understand what they experienced during their first year of in-service teaching. This deeper involvement in the interviews meant that our findings are rich, extensive, and inclusive of relevant data.

From ethical reasons, we were sensitive to our participants' emotional state since their experiences were likely to trigger unsettling memories. Following Leedy and Ormrod (2005), our ethical considerations included ensuring informed consent and maintaining confidentiality, allowing of no deception, and causing no harm to our participants. We explained the aim of the study and the roles of participants to them during the first interview and all participants signed consent forms. They were also assured that their responses would be handled confidentially and that their identities would be protected by the use of pseudonyms. No deception occurred since the participants were informed about the exact purpose of the research which was not harmful to them and they had the option to withdraw at any stage of the study with no negative consequences if they chose to do so.

\section{Research design}

As mentioned above, the chosen research design was a case study (Maree, 2016). We argue for the suitability of our chosen design by drawing on the work of Zainal (2007, p. 2) who said,

Case studies, in their true essence, explore and investigate contemporary real-life phenomenon through detailed contextual analysis of a limited number of events or conditions, and their relationships.

In this paper, the contemporary real-life phenomenon under scrutiny was the influence of beginner teachers' choice of tertiary institution on their emergent beginner teacher identities. Aligned with Zainal's (2007) view, we acknowledge that there are many factors influencing beginner teacher identity construction, but the focus of this paper is on the choice of tertiary institution as influence on beginner teacher identity. Zainal (2007) further described case study research as an in-depth inquiry into participants' life experiences in terms of the interrelationship between contextual settings and the research question being asked. Using a case study research design from this perspective allowed us to gain a deeper understanding of the influences of the choice of a part-time as opposed to a full-time higher education programme on beginner teacher identities. Additionally, the case study research design provided us with the opportunity for collaboration with participants within their own environments as advocated by Cohen et al. (2007). In this case, the implied environment was the space in which participants found themselves during their teacher training — studying via a part-time higher education institution while working at a school or studying at a full-time higher education institution. 


\section{Participant selection}

Participant selection was conducted by using purposive sampling following Cohen et al. (2007). In line with the case study as our chosen research design, we opted for a small number of participants since we were interested in data that is detailed, varied, and extensive as suggested by Neuman (1997). In so doing, we were able to conduct an in-depth analysis of our six participants' responses. Of these, as made clear above, three had studied at a part-time higher educational institution and three had studied at a full-time one. Their ages ranged from 24 to 29 years. At the time of the interviews, all participants were beginner teachers and had three or fewer years' teaching experience. Although we acknowledge other terms for this status, we consider beginner teachers as teachers who have been teaching for three or fewer years in line with Fraser et al. (2017), for the purpose of this paper. The only selection criteria we had was that participants had to be beginner teachers and that three had to have studied full-time and three part-time. To aid us with the analysis of data, we grouped the participants informally into two groups. Each pseudonym followed by FT indicates a full-time student while PT indicates a part-time student. Group 1 consisted of participants Nthabiseng, (FT), Angelina, (FT), and Colin, (FT), while group 2 included participants Fred, (PT), Hannah, (PT), and George, (PT). Participants in Group 2 also worked for the duration of their studies either in schools as teaching assistants or in similar school-like educational contexts. The data was collected from participants situated in Pretoria, Gauteng (South Africa) and all participants were employed at fairly well-resourced urban schools.

\section{Data collection and analysis}

Following Cresswell (2008), we collected the data from face-to-face semi-structured interviews. We conducted two interviews of 60 to 90 minutes' duration with each participant. The interviews were steered by a set of semi-structured questions that included some on the participants' understanding of their own teacher identity and the ways in which they perceived these identities. In a conversational manner in line with Uitto (2012), we also discussed their perceptions of the ways in which their teacher identities had been shaped by certain influences and we funnelled our discussion towards the choice of teacher education programme as primary influence on their emerging beginner teacher identities. Finally, a general overview was elicited from participants about their broad experiences during their teacher training and they were free to share any other details or memories with us. To preserve the integrity of the data and ensure that it was interpreted properly, interviews were audio-recorded, and we transcribed them from these recordings and used them repeatedly to go over the interviews and verify what we believed the participants to have said. We used thematic content analysis to analyse the data from the interview transcriptions as advised by Braun and Clarke (2006) who have pointed out that thematic content analysis involves identifying, analysing, and reporting different themes that are supported by the data that is collected. 


\section{Main findings}

Following an analysis of the data, three main themes emerged: diverging perceptions of initial beginner teacher identity states; beginner teacher identity evolving over a period of time; and practical experience being critical to beginner teacher identity.

\section{Diverging perceptions of initial beginner teacher identity states}

Data showed several differences between the perceptions of participants who studied fulltime and those who studied part-time in terms of their perceptions of their initial beginner teacher identity state. However, certain similarities between the two groups were also evident. Participants explained how their initial beginner teacher identities were constantly in flux and were based on the situations that occurred daily in their classrooms. Angelina (FT) revealed how she had to alter her teaching identity to be able to handle ordinary classroom situations. She said, "Coming from a university you have a certain mind-set of how things need to be, and then when you actually start teaching you see that it's completely different, you must change yourself." Hannah (PT) noted how she had to adapt her teaching identity to be able to handle day-to-day situations; she explained that "you get thrown into the deep end, but it teaches you very quickly how to swim and how to become a strong teacher." George (PT) said that "being a part-time student and working in a school environment, gives more clarity on what it truly means to be a teacher." His sense of clarity made him seem more selfconfident, probably because his teacher education programme permitted him to probe into his beginner teacher identity before he had to really start teaching.

It appears that the professional identities of the full-time participants may have been in a more unstable state when they began to teach. They seemed less able to develop their identities without first understanding and maturing their present selves when they found themselves in teaching contexts. This is evident in Colin's (FT) response: "I was not sure of who I [was] when I was a student, only when I started teaching, I became a little bit more sure but not that much." Similarly, Nthabiseng (FT) said, "I felt pressure during my years of studies because I couldn't know how I would turn out as a teacher one day" and for Angelina (FT), "I wasn't really sure what kind of teacher I would be one day, because I haven't been there really, but it got better only when I was a real teacher." Only after they had found and understood their present teaching self within the profession could they formulate and start working toward their future teacher selves.

\section{Beginner teacher identity evolving over a period of time}

Our data showed that time was significant in relation to beginner teacher identity. Participants from both groups agreed that beginner teacher identity construction and development involved time-consuming psychological processes. They related that the time spent in the practice contributed greatly to their beginner teacher identity. Fred (PT) told us how he had "had time to actually make mistakes in class" and could learn from his mistakes by trying new methods. Part-time participants showed more secure beginner teacher identities during their first years in the profession and seemed to have a clearer idea of the fact that teacher 
identity is never completely stable. Fred (PT) said, "I knew I would still change a lot as a teacher because even now when I see other colleagues teaching, I think about it and try things in my class. I also remembered that from when I was studying and working at a school only as an assistant. I realise this thing will take years." Hannah (PT) explained that by working as an assistant teacher while studying part-time, she could try different ideas about what she thought would work for her. This is apparent from her explanation that "at one point, I was basically the teacher for five weeks in the class. And that already helped me, from an early stage, to identify what works for me as a teacher and what doesn't work for me as a teacher so that once I graduated it wouldn't be such a bomb shock for me in class." George (PT) agreed with Hannah (PT), in the sense that his identity was shaped over an extended period. He commented that because he had additional time in a school setting, he had extra time during which to change his beginner teacher identity to feel more self-assured in what he was doing in class. He said, "Creating your identity is a process, which I feel is done over a long period of time, and by studying part-time it was easier to find myself and to stand on my own feet in the educational world."

Full-time participants agreed that the construction of a beginner identity takes time, and they thought that pre-service teachers who studied part-time had had more time for this process to happen. In some cases, full-time participants viewed this as a distinct advantage of having studied part-time. Angelina (FT) said that "all the other teachers starting with me who did it part-time, I feel like they had more of an advantage, and they knew exactly what to expect when walking into a classroom because they had more years working with the kids." Colin (FT) agreed with Angelina (FT) and added, "I believe part-time would have been a better choice because even though you are working, you are not a full-fledged teacher. You are still learning, you are learning by observing and doing a little, and then systematically increasing the amount of work you do." Hannah (PT) explained how her choice of teacher education programme aided her to evolve and adjust her beginner teacher identity even though she was busy studying. She said, "I literally got to grow within a school system, and I got to evolve in my way as a teacher because I was constantly busy with teaching every single day." She said she had additional time to experiment with different ways of teaching and that those teachable instances matured her beginner teacher identity earlier in her years of study. She said that "the institute that I graduated from definitely helped my teacher identity because I went through a trial-and-error stage while I was doing it. I could see what was working for me and what was not working for me." Angelina (FT) made an interesting point about the time available for full-time pre-service teachers when she commented on the demands of being a full-time student by saying, "You know you are studying full-time, so your studies must be the priority. Making sure that you pass is really important, you don't really have time to think about the type of teacher you want to be or will be even if lecturers ask you to think about it."

\section{Practical experience being critical to beginner teacher identity}

Although both groups of participants had vastly different experiences, one aspect upon which they all agreed was the significance of practical experience as part of teacher education 
programmes. Full-time participants felt that their beginner teacher identity would have manifested differently if they had had more practical experience before they started teaching. Angelina (FT) and Colin (FT) made several substantive claims in this regard. Angelina (FT) said, "I believe that if I had studied part-time and worked as a teacher, my teacher identity would have been completely different. Because, then I would have gained more practical experience, working with the kids, hands-on experience." Colin (FT) agreed when he said, "During my short teaching practice, there my teaching identity was formed and shaped, I believe. It gave me the opportunity to prepare for what being a full-time teacher would be. I learned more from teaching practice than I did from my institution." He added, "I believe that if I studied part-time, I might have gotten the opportunity to learn more and be more prepared. Studying part-time would kind of already make you a teacher, so you would have learned from the job." Angelina (FT) stated that she would have valued additional practical experience and that the lack of prolonged practical engagement made her feel lost. As she put it, "When I walked into the classroom, I was completely lost ... I did not feel that I had enough practical experience to be able to work with the kids."

All participants felt confident about the positive impact the practical experience had had on their beginner teacher identity, whether it was more practical experience in the case of parttime participants or less so for full-time participants. Fred (PT) said, "I got my experience from my school, it is out and out because I have been teaching there while I study that gave me the advantage or the experience, to teach like I teach now. They guided and supported me and gave me lots of opportunities." Colin (FT), as a full-time student, concurred with the significance of his practical experience of six months when he said, "It was during teaching practice where we learned, where we worked at schools for six months, there my teaching identity was formed and shaped." George (PT) commented on the way in which his practical experience now elicits a sense of early success when he said, "I also feel practical experience gave me a head start in the teaching industry where I had a lot of experience because I taught and studied part-time. I already know I will make it in the industry. Experience is key to help you find your own teaching identity." Hannah (PT) explained that some of the most important aspects of her beginner teacher identity came from observing other teachers. She said, "I had a lot of examples to learn from, and I had a lot of people that I could grab knowledge from." Nthabiseng (FT) captured the significant role played by practical experience by these powerful words when she said,

When I was actually dealing with problems and seeing how the teachers actually react to certain situations, I could either gain from that or decide for myself that I won't ever handle a child that way. I think there are a lot of influencing factors, that need to be taken into consideration for your beginner teacher identity to grow. But I would definitely label the most important one, the one you cannot go without as practical experience. 


\section{Discussion of findings}

\section{Different routes towards the profession influence beginner teacher identity states}

Pre-service teachers' identities are not fixed, but are, rather, fluid processes involving "interpretation and reinterpretation of experience" (Nichols et al., 2017, p. 407). It was evident from our data that early teacher identity states of former full-time and part-time preservice teachers differed in several ways and that they all had unique visions and goals for their future teaching selves. This is in agreement with the view of Harrison $(2018$, p. 4) who noted,

We all envisage a range of possible identities for ourselves, framed by factors both within and beyond our control ... These possible selves are part of building a wider narrative that we use to make sense of our lives in our own social context.

The participants who studied via full-time teacher education programmes said that they had not yet formed a clear beginner teacher identity before they started teaching and their responses during the interviews suggested an uncertainty about their emerging beginner teacher identity. Marcus and Nurius (1986) explained this process as the idea an individual has of what they want to become. Full-time participants were not sure of who they were as teachers when they started teaching. When describing their beginner teacher identities, the full-time participants spoke about who they "hoped" they might become. This is in line with the view of Marcus and Nurius (1986) whose Possible Selves theory indicates how thoughts about the future has self-relevant goals as its aim and how future-orientated thought provides information relevant to identity formation as confirmed more recently by Hamman et al. (2010).

Both groups of participants expressed individual hopes for the future and spoke about their fears regarding present teaching situations. Teaching is a profession in which feelings and motivation play an important role, and to support pre-service teachers' learning, their feelings, desires, and thoughts must be taken into account (Korthagen, 2017). From the findings elicited from our data, it is safe to say that the beginner teacher identity states of fulltime study participants seemed to shift more frequently between perceptions of their past selves and hopeful visions of their future selves. Additionally, full-time study participants seemed to take longer to construct a clear view of their beginner teacher identity. For all these particular participants, this process began only after they had started teaching. This might imply that their future self was under slightly more pressure since they had to deal with all the demands made on beginner teachers as Deswita (2019) and Klusman et al. (2016) have indicated in different contexts, while attempting to understand and get to know their newly emerging professional personas.

The group who studied part-time while working in schools seemed to have formed a rough image of what they wanted their beginner teacher identity to be or, in some cases, knew that a strong identity had already emerged. For these participants the shift towards a clearer 
beginner teacher identity seems to have started earlier and they also seemed to have a clearer idea of the current state of their teaching selves. They ascribed this to the fact that they had the opportunity to interact directly with learners and teachers in a schooling environment. This finding correlates with the views of Padua and Franca-Carvalho (2019) and Nomlomo and Sosibo, (2016) who emphasised the significance of pedagogical practice as the basis of the contextualisation of teaching experience.

\section{The perceived chasm between tertiary studies and practice}

Participants from both groups mentioned the magnitude of the difference between what they had been taught at their tertiary institution and their experiences during what they referred to as "real-life teaching." These differences were mentioned by all participants irrespective of the route they had chosen to become teachers. Participants compared the content of what they were taught at their respective initial teacher education institutions to how this translated into their experiences in practice. Their views were in line with Gravett's $(2012$, p. 4) descriptions of "studying theory from books and in lectures" and then "applying" it practically in what is termed the "real world." Participants from both groups indicated that they were not sure how different modules were aligned and failed to understand how theoretical content translated into practice. Rusznyak (2015) accounted for this by pointing out that when pre-service teachers failed to understand the fundamental composition of their teacher education programme, they had trouble understanding the relationships between and among the different modules they study. It was evident that the chasm between their tertiary studies and their experiences during their first years in practice influenced their identity formation process. Participants entered their new profession with the expectation that they were comprehensively prepared through their tertiary studies to face initial challenges, which was not always the case.

It is important to note that although the full-time participants had the essential theoretical knowledge, they just did not yet comprehend how to use it practically. This could have added to the feeling of being overwhelmed that they experienced; they had not yet realized that their theoretical knowledge is just as important as their practical experience. Galman (2009) presented another perspective on participants' responses to what they learn during their tertiary training. She viewed the "ubiquitous grumbling" (p. 468) of pre-service teachers as an indication of a possible positive effect of their teacher education program on their preservice teacher identity development. She argued that a phronesis, or practical wisdom approach to pre-service teacher education, may resolve the theory vs. practice problem and added that such an approach will focus mainly on the expansion of practical reasoning or perception-based knowledge, which will assist in effective communication and decisionmaking in a classroom setting. The experiences of dissonance and the emotions related to being overwhelmed, as was evident in participants' responses, may suggest that they are wrestling with novel ideas and moving forward in developing a unique and more stable and secure teacher self. 


\section{The critical role of exposure to practice}

Both groups of participants held strong views about exposure to practice being essential to the construction and development of their beginner teacher identities. Part-time participants thought that they had had more time to develop their beginner teacher identity than had their full-time counterparts and added that they felt adequately prepared for teaching full-time. The choice of teacher education programme determines the amount of practical experience to which pre-service teachers are exposed (Darling-Hammond et al., 2015). Full-time teacher education programmes struggle to provide adequate time for important practical experience, and thus typically place pre-service teachers in schools for limited periods of time (Hofmeyr, 2016).

Beginner teachers' identities are formed to some extent by the ideas and approaches promoted by their teacher education programmes (Anspal et al., 2012; Beauchamp \& Thomas, 2011). From our data it was evident that full-time participants had limited practical involvement compared to part-time participants who worked full-time at schools. The perceived deficiency in practical experience of full-time participants resulted in feelings of being overwhelmed and lost, which meant they could not focus on, nor see the benefits of, their theoretical knowledge. In contrast, our data indicated that prolonged practical experience during formal teacher training had a strong positive influence on the development of the beginner teacher identities of part-time participants. According to Hofmeyr (2016), a key flaw identified in university curricula is a lack of sufficient school practical experience. This is confirmed by the findings of our study.

\section{Conclusion}

Among other factors not explored in this paper, our findings suggest that different teacher education programmes influence the emergent beginner teacher identity of teachers during their early years of teaching to a considerable extent. Our findings show that exposure to practical experience in the school environment played a significant role in the development of beginner teacher identity. Consequently, the extent of opportunities for practical experience offered by different higher education institutions might constitute a substantial link to the development of beginner teacher identity.

From participants' shared lived experiences, we were able to recognise processes of growth and transformation in pre-service teachers during their years of study as they experienced the different routes to qualification with some similarities in the experiences of those who chose the same route. Although intrinsic desire and motivation of both full-time and part-time students, among other factors, eventually determines their classroom success (Hofmeyr, 2016) we hold the view that the choice of teacher educator programmes is a factor that cannot be ignored in conversations about teacher training. Additionally, beginner teacher identity may be influenced in a holistic sense by the choice of teacher education programmes in ways that our findings did not show. 
We recognise that the choice of a teacher educator programme is one of the important building blocks that make up the past self of beginner teachers. The past experiences of a beginner teacher cannot be changed or rewoven; they form part of their past selves which is essential to building their future teacher selves. After reflecting on our initial choice of the metaphor of different roads leading to Rome, we are of the opinion that all roads do indeed lead to Rome. However, since these journeys to the desired destination differ so vastly the traveller (becoming-teacher) reaching Rome may be a different teacher had they chosen a different road.

\section{References}

Abongdia, J. A., Adu, E. O., \& Foncha, J. W. (2015). Pre-service teachers' challenges during teaching practice in one university in the Eastern Cape, South Africa. International Journal of Educational Sciences, 11(1), 50-56.

Anspal, T., Eisenschmidt, E., \& Löfström, E. (2012). Finding myself as a teacher: Exploring the shaping of teacher identities through student teachers' narratives. Teachers and Teaching: Theory and Practice, 18(2), 197-216.

Beauchamp, C., \& Thomas, L. (2009). Understanding teacher identity: An overview of issues in the literature and implications for teacher education. Cambridge Journal of Education, 39(2), 175-189.

Beauchamp, C., \& Thomas, L. (2011). Understanding new teachers' professional identities through metaphor. Teaching and Teacher Education, 27, 762-769.

Beijaard, D. (2019). Teacher learning as identity learning: models, practices, and topics. Teachers and Teaching: Theory and Practice, 1-6. https://www.tandfonline.com/doi/full/10.1080/13540602.2019.1542871

Beltman, S., Glass, C., Dinham, J., Chalk, B., \& Nguyen, B. (2015). Drawing identity: Beginning pre-service teachers' professional identities. Issues in Educational Research, 25(3), 225-245.

Braun, V., \& Clarke, V. (2006). Using thematic analysis in psychology. Qualitative Research in Psychology, 3(2), 77-101.

Canrinus, E. T., Helms-Lorenz, M., Beijaard, D., Buitink, J., \& Hofman, A. (2012). Selfefficacy, job satisfaction, motivation and commitment: Exploring the relationships between indicators of teachers' professional identity. European Journal of Psychology of Education, 27(1), 115-132.

Carter, A. (2015). Independent report: Carter review of initial teacher training. Department for Education, England. https://www.gov.uk/government/publications/ carter-reviewof-initial-teacher-training. 
Chan, C. (2019). Crossing institutional borders: Exploring pre-service teacher education partnerships through the lens of border theory. Teaching and Teacher Education, 86, $1-10$.

Cherrington, A. (2017). Positioning a practice of hope in South African teacher education programmes. Educational Research for Social Change, 6(1), 72-86.

Christophersen, K. A., Elstad, E., Turmo, A., \& Solhaug, T. (2016). Teacher education programmes and their contribution to student teacher efficacy in classroom management and pupil engagement. Scandinavian Journal of Educational Research, 60(2), 240-254.

Chubbuck, S. M., Clift, R. T., Allard, J., \& Quinlan, J. (2001). Playing it safe as a novice teacher: Implications for programs for new teachers. Journal of Teacher Education, 52(5), 365-376.

Clandinin, D. J. (1995). Still learning to teach. In T. Russell \& F. Korthagen (Eds.), Teachers who teach teachers pp. 25-31. Falmer Press.

Cohen, L., Manion, L., \& Morrison, K. (2007). Research Methods in Education (6th ed.). Routledge.

Corcoran, E. (1981). Transition shock: The beginning teacher's paradox. Journal of Teacher Education, 32(3), 19-23.

Creswell, J. W. (2008). Educational research: Planning, conducting, and evaluating quantitative and qualitative research (3rd ed.). Merrill Prentice Hall.

Darling-Hammond, L. (2015). Teacher quality and student achievement. Education Policy Analysis Archives, 8, 1. https://epaa.asu.edu/ojs/article/view/392/515

Darling-Hammond, L., Hammerness, K., Grossman, P., Rust, F., \& Shulman, L. (2005). The design of teacher education programs. In L. Darling-Hammond \& J. Bransford (Eds.), Preparing teachers for a changing world: What teachers should learn and be able to do (pp. 390-441). Josey-Bass.

Davis, B. H., \& Cearley-Key, T. (2016). Teacher fellows: A school/university partnership for beginning teachers. In T. Petty, A. Good \& S. M. Putman (Eds.), Handbook of research on professional development for quality teaching and learning (pp. 281294). IGI Global.

Denzin, N. K., \& Lincoln, Y. S. (2008). The landscape of qualitative research (vol. 1). SAGE.

Department of Higher Education and Training. (2015). National Qualifications Framework Act 67 of 2008: Revised policy on the minimum requirements for teacher education qualifications. Government Gazette, South Africa, 583 (38487). 
Deswita, Y. (2019, December). Implementation of beginner Teacher Induction Program (PIGP) in city of Solok. In International Conference on Education Technology (ICoET 2019). Advances in Social Science, Education and Humanities Research, 372, 332-335. Atlantis Press. https://www.atlantis-press.com/article/125925105

Dicke, T., Parker, P. D., Marsh, H. W., Kunter, M., Schmeck, A., \& Leutner, D., (2014), Self-efficacy in classroom management, classroom disturbances, and emotional exhaustion: A moderated mediation analysis of teacher candidates. Journal of Educational Psychology, 106, 569-583.

Du Plessis, A. E., \& Sunde, E. (2017). The workplace experiences of beginning teachers in three countries: A message for initial teacher education from the field. Journal of Education for Teaching, 43(2), 132-150.

Feiman-Nemser, S. (2001). From preparation to practice. Designing a continuum to strengthen and sustain teaching. Teachers College Record, 103(6), 1013-1055.

Flores, M. A. (2017). Practice, theory and research in initial teacher education: International perspectives. European Journal of Teacher Education, 40(3), 287-290.

Flores, M. A., \& Day, C. (2006). Contexts which shape and reshape new teachers' identities: A multi-perspective study. Teaching and Teacher Education, 22(2), 219-232.

Fraser, K., Greenfield, R., \& Pancini, G. (2017). Conceptualising institutional support for early, mid, and later career teachers. International Journal for Academic Development, 22(2), 157-169.

Friedman, I. A. (2000). Burnout in teachers: Shattered dreams of impeccable professional performance. Journal of Clinical Psychology, 56(5), 595-606.

Galman, S. (2009). Doth the lady protest too much? Pre-service teachers and the experience of dissonance as a catalyst for development. Teaching and Teacher Education, 25(3), 468-481.

Gravett, S. (2012). Crossing the "theory-practice divide": Learning to be(come) a teacher. South African Journal of Childhood Education, 2(2), 1-14.

Gravett, S., de Beer, J., Odendaal-Kroon, R., \& Merseth, K. K. (2017). The affordances of case-based teaching for the professional learning of student-teachers. Journal of Curriculum Studies, 49(3), 369-390.

Grossman, P., Hammerness, K., \& McDonald, M. (2009). Redefining teaching, re $\square$ imagining teacher education. Teachers and Teaching: Theory and Practice, 15(2), 273-289.

Hamman, D., Coward, F., Johnson, L., Lambert, M., Zhou, L. \& Indiatsi, J. (2013). Teacher possible selves: How thinking about the future contributes to the formation of professional identity. Self and Identity, 12(3), 307-336. 
Hamman, D., Gosselin, K., Romano, J., \& Bunuan, R. (2010). Using Possible-Selves theory to understand the identity development of new teachers. Teaching and Teacher Education, 26(7), 1349-1361.

Harrison, N. (2018). Using the lens of 'possible selves' to explore access to higher education: A new conceptual model for practice, policy, and research. Social Sciences, 7(10), 209-230.

Hobson, A. J., Ashby, P., Malderez, A., \& Tomlinson, P. D. (2009). Mentoring beginning teachers: What we know and what we don't. Teaching and Teacher Education, 25(1), 207-216.

Hofmeyr, J. (2016). International literature review on alternative initial teacher education pathways. Prepared for the Zenex Foundation, Johannesburg. JET Education Services.

Hong, J. Y. (2010). Pre-service and beginning teachers' professional identity and its relation to dropping out of the profession. Teaching and Teacher Education, 26(8), 15301543.

Huberman, M. A. (1989). The professional life cycle of teachers. Teachers College Record, 91, 31-57.

Klusmann, U., Richter, D., \& Lüdtke, O. (2016). Teachers' emotional exhaustion is negatively related to students' achievement: Evidence from a large-scale assessment study. Journal of Educational Psychology, 108(8), 1193-1199.

Korthagen, F. A., Kessels, J., Koster, B., Lagerwerf, B., Wubbels, T. (2001). Linking practice and theory: The pedagogy of realistic teacher education. Lawrence Erlbaum Associates Publishers.

Korthagen, F. A. (2017). Inconvenient truths about teacher learning: Towards professional development 3.0. Teachers and Teaching, 23(4), 387-405.

Kumazawa, M. (2013). Gaps too large: Four novice EFL teachers' self-concept and motivation. Teaching and Teacher Education, 33, 45-55.

Lambert, J., \& Gong, Y. (2010). 21st century paradigms for pre-service teacher technology preparation. Computers in the Schools, 27(1), 54-70.

Langsford, D. (2020). 'Those who can think, teach': The pedagogical reasoning of preservice teachers from different initial teacher education pathways (Unpublished doctoral dissertation).University of the Witwatersrand, Johannesburg, RSA.

Lee, S. A., \& Schallert, D. L. (2016). Becoming a teacher: Coordinating past, present, and future selves with perspectival understandings about teaching. Teaching and Teacher Education, 56, 72-83. 
Leedy, P., \& Ormrod, J. (2005). Practical research: Planning and design (8th ed). Pearson Education Inc.

Levine, A. (2006). Educating school teachers. The Education Schools Project, 38(10), 1-14.

Lortie, D. (1975). Schoolteacher. University of Chicago Press.

Maphalala, M., \& Mpofu, N. (2019). South Africa must up its game and produce more teachers. The Conversation, November 13. https://theconversation.com/south-africamust-up-its-game-and-produce-more-teachers-125752

Marcus, H., \& Nurius, P. (1986). Possible selves. American Psychologist, 41(9), 954-969.

Maree, K. (2016). First steps in research. Van Schaik.

Mitchell, B. C. (2014). The meaning of (student) life. HuffPost. https://www.huffingtonpost.com/dr-brian-c-mitchell/the-meaning-of-studentli_b_4252267.html

Neuman, D. (1997). Learning and the digital library. Library Trends, 45(4), 687-707.

Nichols, S. L., Schutz, P. A., Rodgers, K., \& Bilica, K. (2017). Early career teachers' emotion and emerging teacher identities. Teachers and Teaching, 23(4), 406-421.

Nomlomo, V., \& Sosibo, Z. (2016). From theory to practice: Beginner teachers' experiences of the rigour of the Postgraduate Certificate in Education programme. Perspectives in Education, 34(1), 199-215.

Pádua, C. A. L. de O., \& França-Carvalho, A. D. (2019). The beginner teacher and school culture learning. International Journal of Advanced Engineering Research and Science, 6(10), 26-32.

Pillen, M. T., Den Brok, P. J., \& Beijaard, D. (2013). Profiles and change in beginning teachers' professional identity tensions. Teaching and Teacher Education, 34, 86-97.

Rusznyak, L. (2015). Knowledge selection in initial teacher education programmes and its implications for curricular coherence. Journal of Education, 60, 7-20.

Shulman, L. (1999) Taking learning seriously. Change: The Magazine of Higher Learning, 31(4), 10-17.

Snape, D., Ormston, R., Spencer, L., \& Barnard, M. (2014). The foundations of qualitative research. Qualitative Research Practice: A Guide for Social Science Students and Researchers, 2, 52-55. 
Stokking, K., Leenders, F., De Jong, J., \& Van Tartwijk, J. (2003). From student to teacher: Reducing practice shock and early dropout in the teaching profession. European Journal of Teacher Education, 26(3), 329-350.

Storey, G. R. (2008). The population of ancient Rome. Gale Group, Farmington Hills.

Tamrat, W., \& Teferra, D. (2020). COVID-19 poses a serious threat to higher education. University World News, 9 April. https://www.universityworldnews.com/post.php?story=20200409103755715

Uitto, M. (2012). 'Behind every profession is a person': Students' written memories of their own teacher-student relationships. Teaching and Teacher Education, 28(2), 293-301.

Woest, Y. (2018). Beginner teachers' experiences of transdisciplinary demands of a school curriculum. The Journal for Transdisciplinary Research in Southern Africa, 14(2), 17.

Yavuz Tabak, B., Yenel, K., Tabak, H., \& Şahin, F. (2020). Prospective teachers' expectations and concerns about the future: Using Possible Selves theory. Journal of Education. https://doi-org.uplib.idm.oclc.org/10.1177\%2F0022057420903260.

Yuan, R., \& Lee, I. (2016). "I need to be strong and competent": A narrative inquiry of a student-teacher's emotions and identities in teaching practicum. Teachers and Teaching: Theory and Practice, 22(7), 819-841.

Yuliyana, Y. (2019). The identity construction of newcomer teachers in English education through reflective writing. BAHTER: Jurnal Pendidikan Bahasa dan Sastra, 18(2), $148-154$.

Zainal, Z. (2007). Case study as a research method. Jurnal Kemanusiaan, 9, 1-6.

Zartman, I. W., \& Goodrick, D. (2005). Comparative case studies. International negotiation. Florence: UNICEF Office of Research, 105(9), 3-15.

Zeichner, K. (2010). Rethinking the connections between campus courses and field experiences in college-and university-based teacher education. Journal of Teacher Education, 61(1/2), 89-99. 